\title{
Original Intents: Individual Requirements for Candidates of Regional Representative Council
}

\author{
Ganiviantara Pratama \\ ganiviantarapratama@gmail.com \\ Faculty of Law, Universitas Lampung
}

Submitted: Okt 14, 2020; Reviewed: Okt 28, 2020; Accepted: Nov 26, 2020

\begin{tabular}{lccc}
\hline & Article's Information \\
\hline Keywords: & DPD; & Original; & Candidate; \\
Individual. & & & \\
& &
\end{tabular}

DOI:

https://doi.org/10.25041/constitutionale.v1i2.2137

Abstract
The main problem of this research is
that there is no firmness regarding the
diction of individual words in the
Constitution which is useful as a
condition for nominating Regional
Representative Council or Dewan
Perwakilan Daerah (DPD)
membership. This indecisiveness has
led to the composition of DPD
membership being dominated by
members of political parties. This
journal aims to explore the meaning
of the diction of words contained in
the 1945 NRI Constitution, namely
"Individual" which is clearly written
in Article $22 \mathrm{E}$ paragraph (4) of the
1945 Constitution of the Republic of
Indonesia after the Constitutional
Court Decision No30/PUU-
XVI/2018. The meaning of the term
"individual" in this article will
determine the conditions for
nominating members of the DPD so
that they are more in line with the
objectives of establishing the
institution. This journal uses a
statutory approach and a historical
approach. The results of this
discussion show that the original
intense definition concluded by the




author regarding the word
"individual" in the 1945 Constitution
of the Republic of Indonesia after the
Constitutional Court Decision has the
following meaning: an individual
who does not have a political party
background or political party
management and really understands
his / her region.

\section{A. Introduction}

Amendments to the 1945 Constitution (UUD 1945) during the reform period resulted in several new institutions. This new institution is expected to give a different color in order to improve the constitutional system in Indonesia. ${ }^{1}$ Precisely in the third amendment to the 1945 Constitution, several new institutions emerged. There were several representative institutions such as the first, the People's Representative Council (DPR) and the second, the Regional Representative Council or Dewan Perwakilan Daerah (DPD). Especially for regional delegates that have been removed because they are considered to hinder democracy. ${ }^{2}$ Regional Delegates are replaced by representative institutions, namely DPD. ${ }^{3}$

The urgency of the presence of the DPD is useful for filling regional representation in the constitutional system in Indonesia. ${ }^{4}$ According to Muchammad Ali Safa'at, the construction of the DPD institution is not closely related to two things; Firstly, is related to the emergence of demands for democratization of filling in class members in the composition of the MPR whose existence is replaced by the existence of the DPD; secondly, there is an urge to implement regional autonomy which, if not regulated in a wise manner, will have an impact on demands for separatism. ${ }^{5}$ This urgency shows the important role of the DPD institution in maintaining the integrity of the Unitary State of the Republic of Indonesia or Negara Kesatuan Republik Indonesia (NKRI). ${ }^{6}$

The requirements for electing DPD members in the constitution have been rigidly determined. ${ }^{7}$ Article 22E paragraph (4) of the 1945 Constitution of the Republic of Indonesia affirms that people who are participating in the general election (Election) to elect DPD members are Individuals. Constitutions, which should be general and abstract, often create spaces for different interpretations in their implementation. The wrong interpretation by legislators in interpreting the meaning of the word individual will diminish the actual function of the institution. ${ }^{8}$

\footnotetext{
${ }^{1}$ Sri Soemantri M, Reformasi Konstitusi, dalam (Jurnal Sosial Politik Dialektika, Vol. 2 No. 2, 2001),pg 6

${ }^{2}$ Majelis Permusyawaratan Rakyat Republik Indonesia, Buku Keempat Jilid I A: Risalah Rapat Komisi A Ke-1 s/d ke-3 Tanggal 4 s/d 6 November 2011, Masa Sidang Tahunan MPR RI Tahun 2001, (Sekretariat Jenderal Majelis Permusyawaratan Rakyat Republik Indonesia: Jakarta, 2001), pg. 73.

${ }^{3}$ Ibid. pg 66

${ }^{4}$ Andryan M. Solly Lubis, Suhaidi, Faisal Akbar Nasution.2013. "Penguatan Fungsi Legislasi Dewan Perwakilan Daerah dalam Sistem Ketatanegaraan Indonesia (analisis putusan Mahkamah Konstitusi No.29/PPU-X/2012", USU Law Journal, Vol.3 No.2. pg.56.

${ }^{5}$ Muchammad Ali Safa'at, Parlemen Bikameral, (Malang: Universitas Brawijaya Press, 2010), pg 95.

${ }^{6}$ Ibnu SIna Chandranegara, 2014. "Fungsi Falsafah Negara Dalam Penerapan Konsep Negara Hukum", Jurnal Cita Hukum, Vol.2, No.1, pg 53.

${ }^{7}$ Sri Soemantri. 2001. Reformasi Konstitusi, Jurnal Sosial Politik Dialektika, Vol. 2 No. 2.

${ }^{8}$ Jailani, 2015."Sistem Demokrasi di Indonesia dari Sudut Hukum Ketatanegaraan", Jurnal Inovatif, Volume VIII, No.1, pg 5.
} 
The result is that there are more than $50 \%$ of DPD members are from political party backgrounds. Data shows that Seventy-eight (78) of the One Hundred Thirty-Two (132) DPD members elected in the 2019 Legislative Election are administrators or former administrators of political parties. Here are the details of members with political party backgrounds; Twentyeight (28) were from Hanura, Fourteen (14) were from the Karya Group, Eight (8) were from PPP, Six (6) were from PKS, Five (5) were from PKS, Three (3) were from Democrats, Three (3) from PKB, Two (2) from PDIP, Two (2) from Aceh Party, One (1) from Nasdem, One (1) from Gerindra, One (1) from PDS, One (1) is from the Labor Party, One (1) is from the PNI Marhaenisme, One (1) is from PPIB, One (1) is from the Idaman Party. ${ }^{9}$

The polemic regarding the composition of the DPD membership which is dominated by political parties has caused an imbalance in the body of these institutions to be able to channel regional aspirations to the center. ${ }^{10}$ This polemic led to the publication of the Constitutional Court Decision No. 30/PUU-XVI/2018 which contains a prohibition for party leaders running for DPD members in the 2019 General Election.

Based on this background, the problem formulations that can be used in writing this article are; what are the individual requirements for DPD candidates after the issuance of the Constitutional Court Decision No. 30/PUU-XVI/2018?

\section{B. Discussion}

The substance regarding the requirements for individual candidates for Regional Representative Council or Dewan Perwakilan Daerah (DPD) members in the 1945 Constitution of the Republic of Indonesia is a distinct feature that distinguishes between the requirements to run for membership in the DPR. This requirement is useful to show that the DPR and DPD are institutions with different representation. The DPR represents political interests and the DPD represents regional interests. ${ }^{11}$ According to Satya Arinanto, the idea of the DPD's needs in the state administration system of the Republic of Indonesia existed before the 1999 elections were held, namely as a form of refinement of the Regional Representatives in the People's Consultative Assembly or Majelis Permusyawaratan Rakyat (MPR) who had not carried out their functions properly due to the political system created by the government at that time. ${ }^{12}$

The provisions regarding the requirements for becoming a DPD candidate are contained in the provisions of the 1945 Constitution of the Republic of Indonesia, namely article 22E Paragraph (4) of the 1945 Constitution which explains that the term "individual" is the sole condition in the Indonesian constitution for electing DPD members. This requirement is regulated in Law Number 7 of 2017 concerning General Elections. Constitutional Court Decision No. 30/PUU-XVI/2018 emerged due to the violation of citizens' rights as a result of a DPD candidate with a political party background in the 2019 Election. The article that was tested materially was Article 182 letter I of the Election Law which explained; ${ }^{13}$ that in order to become a member of the election, a person is prohibited from holding concurrent positions. These positions have been determined in this law. Some of the prohibited professions are

\footnotetext{
9 Sutan Sorik, "Pengurus Parpol Dilarang Jadi Anggota DPD: Kepentingan Politik Praktis atau Amanah Konstitusi?"http://www.politik.lipi.go.id/kolom/kolom-2/politik-nasional/1249-pengurus-parpol-dilarang-jadi-anggota-dpdkepentingan-politik-praktis-atau-amanahkonstitusi\#ftn5 accessed pada 7 Juni 2020.

${ }^{10}$ Hezron Sabar Rotua, "REKONSTRUKSI KONSTITUSI DALAM REGIONAL REPRESENTATIVE DEWAN PERWAKILAN DAERAH TERHADAP FUNGSI LEGISLATIF", Masalah-Masalah Hukum, Vol. 48, No.3, (2019), pg. 267.

${ }^{11}$ Zulkarnain Ridlwan, 2015. Cita Demokrasi Indonesia dalam Politik Hukum Pengawasan Dewan Perwakilan Rakyat terhadap Pemerintah, Jurnal Konstitusi, Vol. 12, Nomor 2. pg. 32.

12 Satya Arinanto, Kedudukan dan Peranan Dewan Perwakilan Daerah Dalam Sistem Ketatnegaraan Indonesia, (disampaikan dalam Seminar Dewan Perwakilan Daerah dan Mekanisme Kerja Internal di Yogyakarta, 2003), pg 1.

13 Putusan Mahkamah Konstitusi Nomor 30/PUU-XVI/2018 tentang pengujian Undang-Undang Nomor 7 Tahun 2017 tentang Pemilihan Umum. pg. 4.
} 
notaries, public accountants, lawyers/advocates, Land Titles Registrar or Pejabat Pembuat Akta Tanah (PPAT), as well as other jobs that are considered to have the potential to create conflicts of interest in terms of duties, powers and rights in carrying out their duties as DPD later.

At the end of the Constitutional Court Decision states its ruling to grant the petitioner's entire petition and confirms that political party officials are prohibited from running for election. Examining further the intense original of the word individual in the constitution needs to be understood comprehensively by the legislators. The interpretation of the constitutional judges in the Constitutional Court Decision Number 30 / PUU-XVI / 2018 should be a reference. The constitutional justices stated in their decisions: ${ }^{14}$ With regard to the constitutional design according to the judges' considerations, it contains several things; first, there is a concept that needs to be given a clear line of distinction. The DPD is formed and constructed by the amenders of the UUD to have the function of representing regional interests/regional representation. The interest of the DPD being present in the constitutional system is to become a balancing body for DPR institutions in national forums. Unlike the case with the DPR which is an institution that is useful for representing political interests. Second, the design of the MPR institution which is filled by the People's Representative Council or Dewan Perwakilan Rakyat (DPR) and DPD institutions makes the constitutional design of the Indonesian representative institutions unique. Third, the main focus of the DPD institution is regional interests. Various forms of authority in the fields of legislation, finance as well as forms of supervision and consideration tend to be limited. However, this does not diminish the main objective, namely fighting for regional interests and always striving to provide a balance between national and regional interests. Fourth, it is very clear that DPD members are elected through an election mechanism that is implemented in every province in Indonesia. The nomination must be conducted individually and not connected and through political party institutions.

The views and considerations of judges that are valued as a result of constitutional interpretation are of the view that the conditions determined to prohibit political party officials are correct, because the constitutional design of the DPD institution is a balancing institution and is useful for providing checks and balances in the Indonesian parliamentary system. This balancing form is in order to maximize the performance of the two institutions to bring regional aspirations and interests to the national level. ${ }^{15}$ The next consideration is that there will be dual representation in the MPR when the individual requirements to run for DPD members come from political parties. The judge's opinion regarding this matter was expressed in the Court's decision as follows. The opinion of the judge in the Constitutional Court's decision emphasizes a condition that will create double representation in the MPR, because if the DPD has a membership composition from political parties, there can be double representation with the DPR, because the DPR has the same membership composition of the political parties. This condition, interpreted by the constitutional judges, can indirectly change the constitutional design that the amendment of the 1945 Constitution are trying to shape, because the MPR should be an institution that can represent the interests of political representatives and regional representatives. ${ }^{16}$

Constitutional judges consider the rationale for the DPD in a rational-factual and conceptual manner in deciding this matter. There are several points in the judges' considerations that need to be elaborated. First, is based on the existence of views about

\footnotetext{
${ }^{14}$ Ibid,pg. 36

${ }^{15}$ Salmon E.M Nirahua, "Kedudukan dan Kewenangan Dewan Perwakilan Daerah dalam Sistem Ketatanegaraan Indonesia", Jurnal Hukum, Vol.18, No.4, (2011), pg.588.

${ }^{16}$ Op.Cit, Putusan Mahkamah Konstistusi.., pg. 36 .
} 
political parties. The function that should exist in a political party is the function of communication and political aggregation. Looking at the practice in various countries with a more developed democratic climate, it shows that political parties do not firmly reflect the aspirations of society as a whole. Based on this phenomenon, there is another phenomenon, namely the presence of presidential candidates in the United States who run individually without support from political parties. The embryo or origin of this phenomenon is based on the idea that the communication function is not absolute and the aggregation function of political parties has given rise to the concept of deliberative democracy among academics. This concept developed at the end of the 20th century. The focus of this concept is ordinary citizens who are involved in making political decisions, therefore decision-making does not only rely on those who come from small groups and are exclusively from political parties. ${ }^{17}$

The next argument departs from the concept of deliberative democracy which emphasizes that in fact the role of ordinary citizens is very influential in policy making that will be carried out by the government because political parties are deemed not to have channeled all the aspirations of society. Therefore, to accommodate all the aspirations that exist in Indonesia, both central and regional, a DPD that is free from elements of political parties is needed so that representative institutions carry out their duties and functions optimally in the context of a democratic country. ${ }^{18}$

Historically examining the original intent in the discussion of changes, there are several opinions which confirm that the individual in question is an individual who does not come from a political party. M. Akil Mochtar from F-PG (Golkar Party Faction) stated that the DPD issue must be resolved and put forward as he put it as follows: ${ }^{19}$ "The existing arguments explain that the DPD institution should not be filled by political party members. We think that individual candidates can represent the aspirations that exist in their region. There is a possibility of future phenomenon where future elections will be conducted using the district system. Therefore, it will be possible to have problems in the constituents later. We from the PG-Faction suggest individual provisions for DPD candidates in the Constitution." Apart from M. Akil Mochtar, there are also opinions that are consistent with Asnawi Latief: ${ }^{20}$ reaffirming that the institution used to replace the Delegate Delegation was not a delegation from a political party as well as certain political forces and should have come from the region of origin.

Asnawi Latief's opinion further explains that the essence of the DPD institution is an institution that replaces the Regional Representative, therefore what an individual means is not from a political party or from a certain political force. Apart from this opinion there is an opinion of Syarief Usman bin Yahya which states the following: 21 "there was an objection from Syarief as the representative of the faction when there was a change". It is rigidly listed that there are two items in the general election to elect members of a representative institution. First, the material regarding the DPR which is followed by candidates from political parties, and the second, is the material regarding the DPD which is attended by individual candidates. His objections focus on the amount of participation that people affiliated with political parties have participated in, starting from the national level to the regional representative level (DPRD). Therefore the slots and composition to become candidates for DPD members are

\footnotetext{
${ }^{17}$ Ibid,pg. 45

${ }^{18}$ Budiyono, 2013. Mewujudkan Pemilu 2014 Sebagai Pemilu Demokratis, Fiat Justicia Jurnal Ilmu Hukum Volume. 7 No.3. pg.13

${ }_{19}$ Sekretariat Jenderal MPR RI, Risalah Perubahan Undang-Undang Dasar Negara Repubik Indonesia Tahun 1945 (1999. 2002) Tahun Sidang 2000 Buku Satu (Jakarta: Sekretariat Jenderal MPR RI, 2008),pg. 563.

${ }^{20}$ Ibid.pg 54

${ }^{21}$ Ibid.
} 
sufficient to be followed by individual candidates and not mixed with members of political parties.

Opinions differ and reinforce that in fact individual candidates for the DPD should be free from political parties because the candidates originating from these political parties have already participated in the general election at the national level. A consistent and sustainable opinion was expressed by Soedjarto from F-UG (Utusan Golongan Faction), who recommended that a candidate for DPD member be proposed from outside a political party. He stated: "Soedjarto's thoughts focuses on what is best for DPD members. He thought that the DPR was already a political party person, so the DPD should be proposed by someone outside the circle of the political party system.

The view of F-UG firmly emphasizes that the individual must be interpreted as an individual outside a political party. Similar opinion was also held by Hamdan Zoelva, who is the spokesman for the F-PBB, who conveyed the general views of the factions such as: ${ }^{23}$ the next focus that Hamdan Zoelva tries to explain is related to the lines that bind the candidates. If you look closely at the candidates from the DPR who come from political parties, they will always be obedient to their political party lines. It is different from the life of a DPD institution whose members should truly become representatives and fight for the interests of their region because they are directly elected by the people in that area. So DPD members are only tied to the interests of their region and are not bound by the provisions and directions of a political party. Indeed, both of them are fighting for the interests of the nation and state.

This opinion emphasizes that there must be a demarcation/dividing line between the interests of parties and regional interests so that the aspirations of each region are maximally fought for by the DPD institution. Of course, it will be difficult when cadres of political parties who have a coordinating line with the party's vision and mission are clashed with their duties and obligations in bringing aspirations to their regions. ${ }^{24}$ As a result, there will be a conflict of interest in carrying out their duties and authorities as a DPD member. ${ }^{25}$

The final results of the discussion of changes made by the amendment of the 1945 Constitution of the Republic of Indonesia consist of two (2) factions that agree and disagree. There are five factions that agree and there are four fractions that disagree. The factions that agree include; F-PDU, F-PG, F-KB, F-PBB, F-PDIP, while the factions that do not agree that a candidate must be an individual are; f-UG, F-PDIP, F-Reformation, and Indonesian National Army/Police of the Republic of Indonesia (F-TNI /POLRI).

The Constitutional Court's decision and the considerations of the constitutional judges are very helpful in interpreting what is mandated by the constitution. Rudy stated that interpretation is very useful to reveal the meaning contained in the articles of the Constitution, and useful to provide concrete explanations of cases at hand. ${ }^{26}$ It can be seen that in the context of this problem, the interpretation made by the Constitutional Court as the guardian of constitution is effective in resolving problems faced in a concrete manner in order to protect every citizen's rights.

The authority of interpretation belongs to the Constitutional Court or Mahkamah Konstitusi (MK). This authority is stated in Article 24C paragraph (1) of the 1945 Constitution of the Republic of Indonesia. In connection with this research, the considerations

\footnotetext{
${ }^{22}$ Ibid. pg 76

${ }^{23}$ Ibid, pg. 112.

${ }^{24}$ Zulkarnain Ridlwan, 2012. Negara Hukum Indonesia Kebalikan Nachtwachterstaat, Fiat Justsia Jurnal Ilmu Hukum Volume 5 No.2. pg. 15.

${ }^{25}$ Pan Mohammad Faiz, dan Muhammad Reza Winata, 2019, Respon Konstitusional Larangan Calon Anggota Dewan Perwakilan Daerah sebagai Pengurus Partai Politik, Jurnal Konstitusi, Vol. 16, No.3. pg 45.

${ }^{26}$ Rudy, Mempertimbangkan Amandemen Konstitusi (Kajian Calon Presiden Perseorangan dari Aspek Kedaulatan Rakyat dan Konstitusionalisme),(Fiat Justisia Jurnal Ilmu Hukum Vol. 8 No. 1, 2014), pg 110.
} 
of the Constitutional Court judges will greatly strengthen this research. The decision regarding the DPD membership requirements as stated in Law Number 7 of 2017 concerning General Elections was subject to judicial review at the Constitutional Court on April 4, 2018 by Muhammad Hafidz. The petition concerns individual requirements that exist in the Election Law. Provisions that explain individual requirements are contained in Article 182 letter I of the Election Law, which reads: "Individuals referred to in the provisions in Article 182 can become Election Contestants after fulfilling the following requirements: first, they do not have and come from the profession of lawyers, public accountants, notaries and PPAT as well as professions related to providers of goods and services and state finances, second, they do not have other jobs where there will be a potential conflict of interest if the candidate becomes a DPD member". Other job clauses are still very ambiguous and can lead to misinterpretation of the applicant. The Petitioner asked the Constitutional Court for a review of the article because according to the Petitioner he thought that his rights as a citizen had been violated.

Constitutional judges' considerations regarding the examination of this article began with further examining the functions, duties and authorities of the DPD in the constitutional system. The Constitutional Court Decision Number 30/PUU-XVI/018 is in line with the Constitutional Court Decision Number 10/PUU-VI/2008 regarding the position of the DPD. The Court stated: ${ }^{27}$ the conclusions that can be taken in the judge's consideration are (1) the strict division carried out by the amendment of the 1945 Constitution of the Republic of Indonesia which places the position of the DPD institution in the Indonesian State System as a regional representation or (territorial representation), (2) the task of regional representation is to bring and channel interests, and (3) local votes to a higher level, namely at the national level. This was formed to realize the existence of a check and balance mechanism between the two institutions, namely the DPR and DPD. The DPR is very clear that it is an institution with a function to be a political representation. Second, the peculiarities of the Indonesian representative system are important to note, because it is not just the DPD that is part of a representative institution other than the DPR which will give rise to the idea that Indonesia is a country that uses a bicameral system. Third, seeing that the DPD's authority is very weak and limited to become a representative institution, but even so the construction and constitutional design must continue to be improved and evaluated because this needs to always be endeavored with the consideration of the balance postulate between the national parties and the parties representing the regions. Fourth, emphasized that the DPD must always be elected directly through elections in each province and based on individual candidates and not connected to a political party institution.

The constitutional design determined by the interpretation of the Constitutional Court provides an understanding that the DPD is a regional representation and a counterweight to the DPR in advancing national interests. DPD as a counter body for the DPR must be filled by individual candidates not from political parties. ${ }^{28}$ Based on the constitutional design, DPD members must have a different background from DPR members, because the DPD member's background will determine the form of their representation. The fourth point is emphasized, if a member wants to be included in the category of regional representation, it is not through a political party.

Constitutional judges consider the rationale for the DPD in a rational-factual and conceptual manner. First, from the viewpoint of the ideal functions of political party institutions, the original intent or the origin of the formation of the DPD institution and the

\footnotetext{
${ }^{27}$ Putusan MK Nomor 10/PUU-VI/2008, ,pg. 36

${ }^{28}$ Harry Setya Nugraha, 2017."Pemurnian Sistem Presidensial dan Parlemen dua kamar di Indonesia sebagai gagasan perubahan UUD 1945", Jurnal Hukum Vol. 8 No.1. pg. 22.
} 
Court's decision above cannot be judged to rule out the existence of functions. The ideal of political parties, especially in this context, is the function of communication and political aggregation. Because, even in countries with modern democratic life, political parties cannot be absolutely believed that they have reflected the aspirations of all the people, that is what rationally-factually explains the emergence of phenomenon, including the presence of individual presidential candidates with independent mechanisms in The United States or independent/individual candidates in regional head elections in Indonesia, some of which have succeeded in defeating and subduing candidates submitted by political parties. The idea starts from this argument that affirming the communication and aggregation function of political parties is also the reason for the birth of discourse on deliberative democracy among thinkers in the field of democracy. This idea began in its development at the end of the 20th century, which views the importance of ordinary citizens (lay citizens). The more ordinary people or society involved in the making and determination of a political decision will be able to give color to the argumentation of the policy making and it is not just an elite group represented by a political party. ${ }^{29}$

The judges' first consideration explains that in the constitutional system, individual candidates are needed to advance the democratic process in Indonesia. Representations from political parties have not represented all the aspirations of the people, especially in the regions. Judges' considerations of individual provisions in DPD member candidates according to the author do not have a background from political parties. The judge deliberation's focus seeks to bring forward independent candidates from ordinary citizens to enter the decision-making process at the national level.

The judges' considerations are focused on the composition of the DPD membership, which should not come from political parties because it would indirectly change the structure and construction of the MPR membership which the 1945 Constitution of the Republic of Indonesia attempted to embody. The judge's opinion on this matter was expressed in the Constitutional Court decision as follows. The domino effect that will occur when DPD members come from political parties is first that there will be double representation in the Republic of Indonesia's MPR. Secondly, when the state wants to change the 1945 Constitution of the Republic of Indonesia there will be conditions only with political interests because there are no regional interests in the deliberation process because the DPD is not at all reflect regional interests. Only the reflection of dominant political representatives will decorate the constituents later. ${ }^{30}$

The considerations regarding the prohibition of political party administrators from running as DPD members in this decision which led to changes in the constitutional design of the 1945 Constitution amendment were trying to build a strong philosophical foundation. According to the author, these considerations serve as reinforcement to legitimize the original meaning of the term "individual" in the 1945 Constitution does not mean coming from a political party and being nominated individually.

The philosophical base for the MPR formation is an idea from the founders of the nation who have an insight into the Indonesian nationality, showing that the MPR institution not only shows the existence of political unity ties that arise as a result of the tendencies of various ethnic groups who live in Indonesia but it also covers the idea that the ethnic group referred to in the territory where it lives is part of Indonesia. ${ }^{31}$ The form of one of the wisdoms must be constructed in a forum for a consultative/representative institution then the

\footnotetext{
${ }^{29} \mathrm{Ibid}$, pg. 45

${ }^{30}$ Ibid.

${ }^{31}$ Yulia Neta, 2011. Upaya Peningkatan Peran Dewan Perwakilan Daerah (DPD) di Indonesia, Fiat Justicia Jurnal Ilmu Hukum Vol.5 No.1.
} 
creators of 1945 Constitution named the MPR so that with the hopes and aspirations of the nation, this institution should make strategic political decisions wisely and be able to represent all the votes of the people in majority in Indonesia. ${ }^{32}$ The author argues that in order to carry out the mandate of the constitution, the meaning of the individual being an important part in determining the composition of the MPR needs to be traced systematically and comprehensively.

The consideration of the third constitutional judges is to try to review how the debate over the membership of the MPR is. The discussion of MPR membership which was discussed by the Ad Hoc I Committee of the MPR Working Body explained that the reasons for implementing the principle of representation on the basis of election. This provision became the basis for the idea of rejection regarding the filling of MPR members through appointment, in this case group delegates. ${ }^{33}$ Some of the factions expressed the views which can be concluded as follows: ${ }^{34}$

“... those who are seen and recognized as figures who represent and reflect groups in society, it is likely that there will be double representation in the MPR because of the presence of members who are appointed as double representations, who have the potential to come from the region. While at the same time the regions also have representatives who have been elected by the community through the election, namely members of the DPD. Therefore, in accordance with the principle of representation by election, people who are considered to represent that group are not worthy and deserve to be appointed but must both follow the contestation of the DPD member election, so that in the composition of the DPD membership there are people from group delegates in society it has actually been seen that through the electability of these regional figures in the DPD institution. In such a way it will be possible to anticipate the possibility of multiple representations and at the same time the principle of representation through contestation is also fulfilled...."

This additional note is a reaffirmation that the DPD membership strives to prioritize the principle of representation by election, namely representation based on elections. The DPD membership composition that has been strengthened by the Court according to the author is a strong argument to determine the meaning that individual intentions in DPD candidacy are nominations carried out individually and The reason has also been strengthened by the Court that this is implemented so that there is no double representation in the strict system in the parliament. The addition of this note also confirms that the DPD is not allowed to go through appointment, but must go through a general election.

\section{Conclusions}

The individual requirements in Article 22E Paragraph (4) of the 1945 Constitution have improved in terms of their grammatical meaning after the Constitutional Court Decision Number 30/PUU-XVI /2018. The interpretations raised by the constitutional judges are very helpful in improving the meaning contained in the constitution. The considerations of the constitutional judges in the Constitutional Court decision determined that according to the constitutional design, the Regional Representative Council or Dewan Perwakilan Daerah (DPD) institution should be filled by candidates who did not come from a political party background, even though they were running individually. Furthermore, there is a consideration that DPD members are affiliated with political parties, it is feared that this will lead to double representation in the People's Consultative Assembly or Majelis

\footnotetext{
${ }^{32}$ Taufik Hidayat, 2015. "Penerapan Sistem Soft Bikameral dalam Parlemen di Indonesia", JOM Fakultas Hukum Vol. 2 No. 2.

${ }^{33}$ Op.Cit, Putusan Mahkamah Konstitusi...pg 46.

${ }^{34}$ Ibid.
} 
Permusyawaratan Rakyat (MPR) because political representatives are already filled by the DPR. This paper also explores the intense original aspects of Article 22E Paragraph (4) of the 1945 Constitution, which at the end of the discussion of the amendments to the 1945 Constitution, the majority of factions agreed that what is meant by an individual is a candidate who is not tied to a political party.

\section{Bibliography}

A. Books

Majelis Permusyawaratan Rakyat Republik Indonesia, 2001. Buku Keempat Jilid I A : Risalah Rapat Komisi A Ke-1 s/d ke-3 Tanggal 4 s/d 6 November 2011, Masa Sidang Tahunan MPR RI Tahun 2001. Jakarta: Sekretariat Jenderal Majelis Permusyawaratan Rakyat Republik Indonesia.

Safa'at, Ali, Muchammad, 2010. Parlemen Bikameral, Malang: Universitas Brawijaya Press.

Sekretariat Jenderal MPR RI, 2008, Risalah Perubahan Undang-Undang Dasar Negara Repubik Indonesia Tahun 1945 (1999-2002) Tahun Sidang 2000 Buku Satu Jakarta: Sekretariat Jenderal Majelis Permusyawaratan Rakyat Republik Indonesia.

B. Journals and Articles

Andryan M. Solly Lubis, Suhaidi, Faisal Akbar Nasution.2013. "Penguatan Fungsi Legislasi Dewan Perwakilan Daerah dalam Sistem Ketatanegaraan Indonesia (analisis putusan Mahkamah Konstitusi No.29/PPU- X/2012", USU Law Journal, Vol.3 No.2.

Budiyono, 2013. "Mewujudkan Pemilu 2014 Sebagai Pemilu Demokratis", Fiat Justisia Jurnal Ilmu Hukum Volume. 7 No.3.

Harry Setya Nugraha, 2017."Pemurnian Sistem Presidensial dan Parlemen dua kamar di Indonesia sebagai gagasan perubahan UUD 1945", Jurnal Hukum, Vol. 8, No.1.

Hezron Sabar Rotua,2019. "REKONSTRUKSI KONSTITUSI DALAM REGIONAL REPRESENTATIVE DEWAN PERWAKILAN DAERAH TERHADAP FUNGSI LEGISLATIF", Masalah-Masalah Hukum, Vol. 48, No.3.

Ibnu SIna Chandranegara, 2014. "Fungsi Falsafah Negara Dalam Penerapan Konsep Negara Hukum", Jurnal Cita Hukum, Vol.2, No.1.

Jailani, 2015."Sistem Demokrasi di Indonesia dari Sudut Hukum Ketatanegaraan", Jurnal Inovatif, Volume VIII, No.1.

Pan Mohammad Faiz, dan Muhammad Reza Winata, 2019, "Respon Konstitusional Larangan Calon Anggota Dewan Perwakilan Daerah sebagai Pengurus Partai Politik",Jurnal Konstitusi, Vol. 16, No.3.

Rudy, 2014, "Mempertimbangkan Amandemen Konstitusi (Kajian Calon Presiden Perseorangan dari Aspek Kedaulatan Rakyat dan Konstitusionalisme)", Fiat Justisia Jurnal Ilmu Hukum Vol. 8 No. 1.

Salmon E.M Nirahua, 2011. "Kedudukan dan Kewenangan Dewan Perwakilan Daerah dalam Sistem Ketatanegaraan Indonesia", Jurnal Hukum, Vol.18, No.4.

Satya Arinanto, 2003, "Kedudukan dan Peranan Dewan Perwakilan Daerah Dalam Sistem Ketatnegaraan Indonesia", disampaikan dalam Seminar Dewan Perwakilan Daerah dan Mekanisme Kerja Internal di Yogyakarta.

Sri Soemantri. 2001. "Reformasi Konstitusi”, Jurnal Sosial Politik Dialektika, Vol. 2 No. 2.

Taufik Hidayat, 2015. "Penerapan Sistem Soft Bikameral dalam Parlemen di Indonesia", JOM Fakultas Hukum Vol. 2 No. 2.

Yulia Neta, 2011. "Upaya Peningkatan Peran Dewan Perwakilan Daerah (DPD) di Indonesia", Fiat Justicia Jurnal Ilmu Hukum Vol.5 No.1.

Zulkarnain Ridlwan, 2012. "Negara Hukum Indonesia Kebalikan Nachtwachterstaat", Fiat Justsia Jurnal Ilmu Hukum Volume 5 No.2.

Zulkarnain Ridlwan, 2015. "Cita Demokrasi Indonesia dalam Politik Hukum Pengawasan Dewan Perwakilan Rakyat terhadap Pemerintah”, Jurnal Konstitusi, Vol. 12, Nomor 2. 